\title{
OSTEORADIONECROSIS OF THE JAW INFECTED WITH Actinomyces sp: A CHALLENGE FOR CLINICAL PRACTICE
}

\author{
OSTEONECROSE DE MANDÍBULA INFECTADA COM Actinomyces sp: UM \\ DESAFIO PARA A PRÁTICA CLÍNICA
}

\author{
Luciana Vieira MUNIZ ${ }^{1,3}$; Rafael P. LACERDA ${ }^{2}$; Aline Lauda Freitas CHAVES ${ }^{3}$; \\ João Marcos Arantes SOARES ${ }^{3,4}$; Tiago Johnston LEITÃ ${ }^{4}$; Leandro A BARBOSA ${ }^{5}$; \\ Helio Batista dos SANTOS ${ }^{6}$; Rosy Iara Maciel de Azambuja RIBEIRO ${ }^{7}$ \\ 1. Department of Dentistry, Association Against Cancer of the Midwest Mine, Divinópolis, MG, Brazil; 2. Student of Medicine; \\ Campus Midwest D. Lindu; Federal University of São João del Rei, Divinópolis, MG, Brazil; 3. Hospital São João de Deus, \\ Divinópolis, MG, Brazil; 4. Professor; Department f Medicine, Campus Midwest D. Lindu; Federal University of São João del Rei, \\ Divinópolis, MG, Brazil; 5. Professor, Laboratory of Cellular Biochemistry, Campus Midwest D. Lindu, Federal University of São João \\ del Rei, Divinópolis, MG, Brazil; 6. Professor, Laboratory of Tissue Processing, Campus Midwest D. Lindu, Federal University of São \\ João del Rei, Divinópolis, MG, Brazil; 7. Professor, Laboratory of Experimental Pathology, Campus Midwest D. Lindu, Federal \\ University of São João del Rei, Divinópolis, MG, Brazil. rosy@ufsj.edu.br/rosyiara@gmail.com
}

\begin{abstract}
The Actinomyces $s p$ has been linked to osteoradionecrosis of the jaw. The identification of these bacteria on histopathological findings confers a determining factor of poor prognosis and is related to difficulties of local control of bone necrosis and risk of recurrent infections. The treatment is complicated due to insidious growth pattern of Actinomyces sp. The methods for diagnosis and therapeutic approaches constitute challenges that underscore the need for understanding the risk factors for infection and knowledge about clinical conditions associated with this pathology. The objective of this study is to report two cases of cancer patients suffering from an osteoradionecrosis infection by Actinomyces sp, to describe approaches and discuss therapeutic options in the light of the current literature.
\end{abstract}

KEYWORDS: Actinomycosis. Osteoradionecrosis. 0steonecrosis by bisphosphonates.

\section{INTRODUCTION}

Osteoradionecrosis (ORN) is a major complication resulting from oncological treatment for head and neck cancer (HNC) and can occur in the period of a few months to years after radiotherapy (HANSEN et al., 2006; HALL, 2008; KHOJASTEPOUR et al., 2012; TURNER et al.,2013). Its definition and etiology are still under discussion, but the radiotherapy appears to cause ORN because it affects the small blood vessels of bone, inducing inflammation (endarteritis), which favors the generation of small thrombi that obliterate the vascular lumen and thus interrupt tissue perfusion. Likewise, RT produces an increase in free radicals and alters collagen synthesis. The bone loses its normal cellularity and undergoes fibrosis-atrophy with impairment of its repair and remodeling capacity (CHRCANOVIC et al., 2010). Under such conditions even minimal external trauma causes ulceration, facilitating contamination and infection, and thus favoring bone necrosis (SILVESTRE-RANGIL et al., 2011; TURNER et al.,2013 ). The pathogenesis of ORN is related to induced trauma or spontaneous injury and / or infection, in the intra-oral mucosa, fistulas and pathologic fracture of the mandible. In advanced cases, surgery is generally necessary and in other situations, the disease may prove to be intractable. The incidence of ORN is estimated to be around 5\% to $35 \%$, and varies with the radiation dose, treatment time, and the general state of the patient (HANSEN et al., 2006; HALL, 2008; KHOJASTEPOUR et al., 2012)

Recently, new considerations about ORN and its relationship with infection have been described. The irradiation of the mandible during treatment of tumors in the head and neck region can lead, at a later date, bone damage and in the surrounding soft tissue (KHOJASTEPOUR et al., 2012), reduce the integrity of the oral mucosa, facilitating infection by Actinomyces sp (CHUNG et al., 1998). Infected osteoradionecrosis (IORN) is defined as necrosis of the bone after irradiation of the mandible with clinical signs of infection, and with exposure of bone necrosis, inflammatory infiltrates and fistula formation or bone sequestration (HANSEN et al., 2007). The IORN is typically associated with pathogens such as Candida $s p$. and cariogenic bacteria of the genus Actinomyces (HANSEN et al., 2006; ANDREWS and GRIFFITHS, 2001).

Mandibular actinomycosis is a rare disease, which has been recently described in patients with IORN (HANSEN et al., 2007; ABIR et al., 2013). It is a suppurating, chronic, granulomatous and 
fibrosing disease. It is a relevant condition due to its aggressive and locally destructive nature (RUSSO, 2010; SMITH et al., 2011; ABIR et al., 2013) After the initial infection, the spread of bacteria in the body occurs by direct invasion of tissues, usually fibrotic and relatively avascularized. The main species are $A$. israelli and $A$. gerencseriae (HALL, 2008; FINLEY and BEESON, 2010; ABIR et al., 2013). The infectious process is generally slow with growth of the mass occurring over time. A more rare presentation is an acute abscess which grows rapidly causing pain and trismus (HANSEN et al., 2007; FINLEY and BEESON, 2010).

Colonies of Actinomyces have a very typical morphology in microscopic slides and are thus fairly easy to identify. They tend to create a mass of filamentous bacteria, with variations in the color between the center and periphery of the colony (the so called "sun-ray" effect). PAS, Gram, and silver stains are typically positive (NEVILLE et al, 2002; GOLDBERG et al., 2003). In contrast to the ease of microscopic identification, the clinical significance of finding colonies compatible with Actinomyces in biopsy specimens is often unclear, affecting treatment planning in these cases (KAPLAN et al., 2009). Infection by Actinomyces has also been suggested to be responsible for deterioration in outcome in cases of osteoradionecrosis of the jaws. (HANSEN et al., 2006; KAPLAN et al., 2009)
The objective of this study was reported two cases of cancer patients suffering from an osteoradionecrosis infection by Actinomyces sp, to describe approaches and discuss therapeutic options in the light of the current literature.

\section{Case Reports \\ Case 1}

Patient male, 42 years old, ex-smoker and social drinker. The patient had the diagnosis of nasopharynx squamous cell carcinoma in 2005, staging T2N2M0. Patient was submitted to chemoradiation treatment (Intergroup Protocol 0099 - cisplatin 100mg/m2 D1, 22,43 concomitant with radiotherapy - total dose of radiotherapy performed with linear accelerator of $6 \mathrm{mV}: 7200$ cGys followed by 3 cycles adjuvant chemotherapy with cisplatin (D1) associated with fluorouracil for 96 hours. In 2008 the patient evolved with pain in the right mandibular region and was referred to the Department of Dentistry of the Association Against Cancer of Center West of Minas Gerais/Brazil. He reported a history of a tooth extraction in the affected region in the previous year. On intraoral examination, the patient presented an ulcerated region with exposure of necrotic bone and purulent collection in the body of the mandible. Radiographically a area with diffuse limits was observed (Figure $1 \mathrm{~A}$ ).
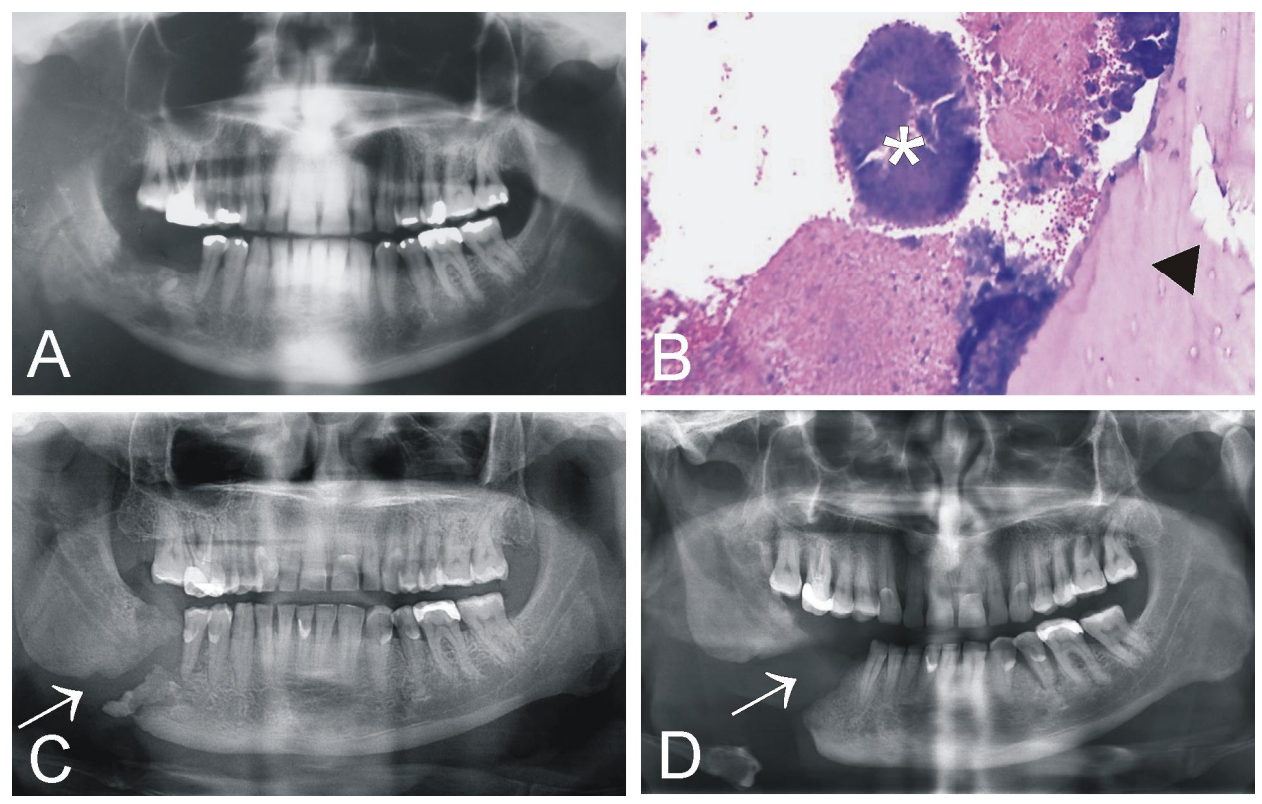

Figure 1. In case 1, panoramic radiography showing the evolution (A, C e D) of the osteonecrosis in infected jaws by Actinomyces sp. colony (B) with bony sequestrate $(\rightarrow)$. observe the presence of Actinomyces sp. colony (*) and bone necrosis (arrowhead) in micrograph. 
A biopsy confirmed the diagnosis of ORN and mandibular infection colonized by Actinomyces $s p$. Microscopy revealed the presence of inflammatory infiltrate with a predominance of lymphocytes and plasma cells, and numerous Actinomyces $s p$ colonies in the intertrabecular tissue (Figure $1 \mathrm{~B}$ ). The fragments of the oral mucosa showed cellular reactive changes in the squamous epithelium. The patient underwent surgery for bone debridement to remove bone sequestration, and was referred to the treatment with long-term antibiotics (ampicillin - every 6 hours). In 2010 patient evolved with neck recurrence and was submitted right neck lymphadenectomy. In 2011, the patient evolved with recurrence of osteonecrosis developed a pathological fracture in the mandibular ramus (figure $1 \mathrm{C}$ ). The patient was submitted to a noninvasive treatment, (sequestrectomy, and extraction of affected tooth - second bicuspid) and long term antibiotics. He is currently asymptomatic and without IORN recurrence in radiography (figure 1D).

\section{Case 2}

Patient female, 76 years of age, nonsmoker, non-drinker. In 2006, she was diagnosed with squamous cell carcinoma of the tongue, stage T2N1M0. She underwent surgery (partial glossectomy and radical neck dissection) and radiotherapy treatment with linear accelerator of 6 $\mathrm{mV}$ (total dose: $6120 \mathrm{cGys}$ ).

In 2007, the patient developed pain in the right mandible and radiographic findings revealed a radiolucent lesion (figure $2 \mathrm{~A}-\mathrm{B}$ ).
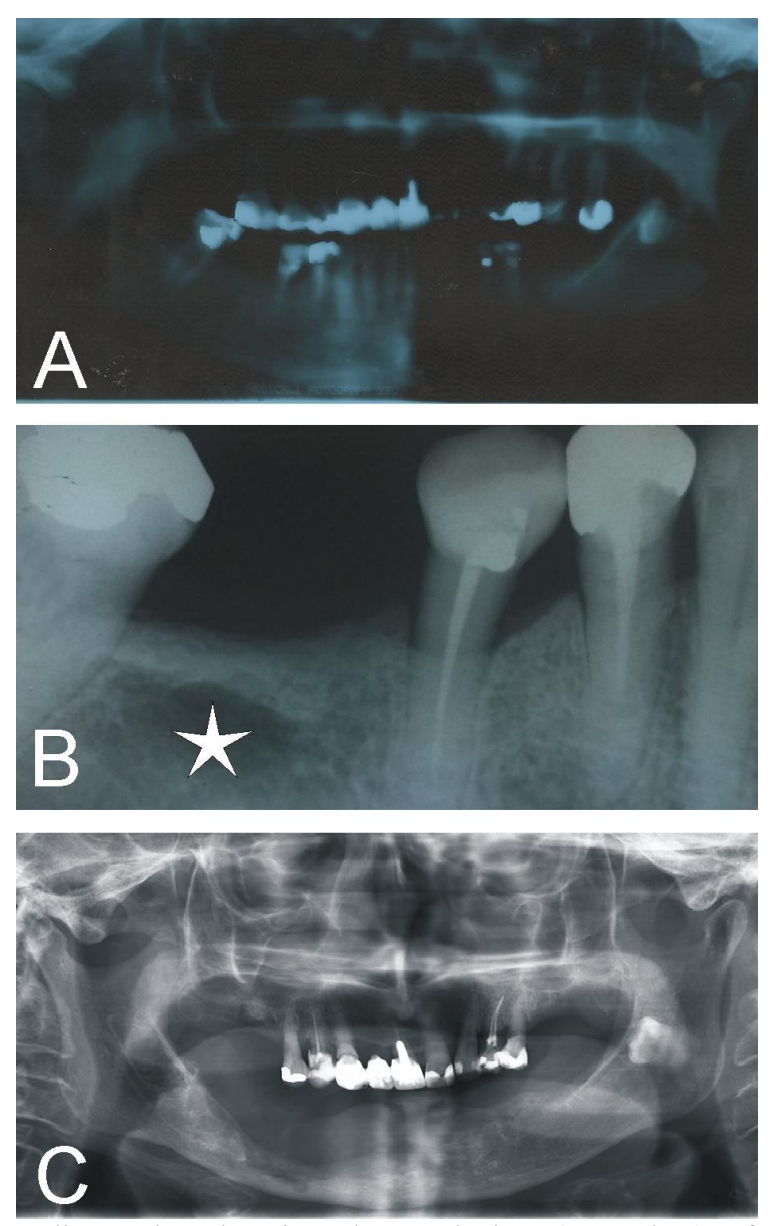

Figure 2. In case 2, panoramic radiography showing the evolution (A and $\mathrm{C}$ ) of the IORN and extensive alveolar bone destruction and (B) periapical radiography showing early signs and detail of radiolucent bone area with diffuse limits (star).

The intraoral examination showed ta fistula of the right gingival ridge. Imaging studies showed osteolytic areas of the bone. In order to relieve his symptoms and reach a diagnosis, debridement of the infected area (including removal of the bony sequestra) was undertaken and the tissue was sent for histological examination. The histopathological examination confirmed an infection with 
actinomycosis associated with osteoradionecrosis. The patient underwent treatment with long-term antibiotics (ampicillin - every 6 hours) and observe satisfactory local control of disease for ten months. In subsequent years (2008 and 2009) new biopsies were performed that revealed recurrences of actinomycosis infection. In March 2011, the intraoral examination revealed progression of bone necrosis with periodontal bone involvement, of some dental elements. The bone debridement and extractions of affected teeth were performed. Histopathological analysis of the bone fragments revealed persistent infection by Actinomyces $s p$. Antibiotic therapy was reinitiated and the patient is systematic monitoring of the multidisciplinary team (head and neck surgeon, infectious disease specialist, and dentist). The patient is currently alive without tumor recurrence. Nevertheless she lost gradually the alveolar bone due to osteoradionecrosis and thereafter the lower teeth (figure C). We could not perform the prosthetic oral rehabilitation. The patient is unable to ingest solid food. Because of this complication, the patient has important functional and aesthetic limitation that interfere with quality of life.

\section{DISCUSSION}

The possible role of $A$. israelii in infected osteoradionecrosis (IORN) was described in 1983 (HAPPONEN et al., 1983). The authors reported five cases in which actinomycosis was confirmed by histopathologic examination with identification of A. israelii. However, in the same year, Marx (MARX, 1983) challenged the concept of infectious etiology of ORN and suggested that the microorganisms detected were only superficial contaminants.

Actinomycosis was again associated with infected osteoradionecrosis in 2000, when Curi et al (2000) reported the diagnosis of $12 \%$ of 50 cases of mandibular osteoradionecrosis, based on histological evidence. The findings of this study demonstrated a significant increase in the time required for remission of ORN in cases of positive Actinomyces.

Bacteria A. israelii and A. gerencseriae are the main causative agents of actinomycosis associated with maxillary IORN, while $A$. odontolyticus, A. meyeri, A. naeslundii / A. viscosus and Propionibacterium propionicum are less frequently implicated (PULVERER et al., 2003).

More recently, Store et al., taking great care to eliminate surface contamination, examined 12 deep medullary specimens of resected mandibles by
DNA-DNA hybridization. Using the checkerboard method with probes for A. israelii, A. gerencseriae, $A$. viscosus and 17 other oral organisms, multiple species including $A$. viscosus and/or $A$. gerencseriae were detected in all of 12 samples. In this same work, multiple species, including A. viscosus and / or A. gerencseriae were detected in the 11 samples (STORE, ERIBE and OLSEN, 2005).

The study by Hansen et al. (2006) histological evidence of actinomycosis was found in 29 of 31 cases of IORN at a frequency of $64.5 \%$ (HANSEN et al., 2006). Sulfur granules were seen almost exclusively in areas of bone necrosis, suggesting a true infection, rather than surface contamination postulated by some authors. They concluded that actinomycosis occurs more frequently $(64.5 \%)$ in ORN than previously thought. Furthermore, they demonstrated that $38.1 \%$ of the patients developed IORN after extraction of teeth, proving the common knowledge that dental extractions are associated with the risk of developing IORN. This study confirms previous findings by Curi et al (2000) which suggested that an Actinomyces positive bone biopsy indicated a worsened prognosis.

Another study by Hansen et al. (2006) investigated patients diagnosed with actinomycosis, with special attention paid to the underlying disease. Forty-five patients were included in the study and 43 presented a diagnosis of osteonecrosis with bisphosphonates $(58.7 \%)$ and IORN (35.6\%). Only three patients $(6.7 \%)$ presented without a history of cancer treatment. In all cases, they found a direct association between Actinomyces colonies and bone in the space surrounding the bone marrow. Inflammatory infiltrates with varying amounts of osteoclasts were a typical finding. Furthermore, pseudoepitheliomatous hyperplasia occurred in $60.9 \%$ of patients.

This study reported cases of patients undergoing oncological treatment who developed late complications related to cervicofacial radiotherapy. The cancer treatment conferred allowed the locoregional control of the disease and these patients completed six years of disease-free survival. However, complications arising from treatment interfered negatively on quality of life of these patients. The etiology of the first case reported probably occurred through contamination of the socket after tooth extraction in a patient with a history of cervicofacial irradiation and compromised healing. The second case showed no correlation to ORN with an identifiable precipitating factor. The therapeutic conduct instituted consisted of treatment with oral antibiotics for a prolonged period, and 
surgical approach for bone debridement, in order to prevent recurrence. In both cases, there were difficulties in controlling the disease site, and frequent recurrences of infection and progression of bone necrosis. The clinical findings and therapeutic results of this study confirmed previous studies that described a poor prognosis for patients affected by IORN from Actinomyces sp ( HANSEN et al., 2006; HANSEN et al., 2007; VAN HALL, 2007; KAPLAN I et al., 2009).

Therefore, according of the findings the presence of Actinomyces $s p$ in histological findings constitutes a poor prognostic factor, and treatmentrelated sequelae affect quality of life and increase the costs of care.

\section{CONCLUSION}

Osteoradionecrosis is a major challenge with regard to therapeutic conduct and patient rehabilitation. The presence of Actinomyces $s p$ is a poor prognostic factor related to the control of the disease, causes significant morbidity and, consequently, a considerable impact on quality of life of the patient. Understanding the risk factors related to the pathogenesis becomes imperative for the development of protocols for the prevention and management of this disease.

RESUMO: O Actinomyces sp tem sido associado a osteorradionecrose. A identificação desta bactéria confere um fator determinante de mau prognóstico e está relacionado a dificuldades do controle da necrose óssea local e a risco de infecções recorrentes. O tratamento é complicado devido ao padrão de crescimento insidioso do Actinomyces sp. Os métodos de diagnóstico e as abordagens terapêuticas constituem desafios que reforçam a necessidade de compreender os fatores de risco para a infecção e o conhecimento sobre as condições clínicas associadas a esta patologia. O objetivo deste trabalho é relatar dois casos clínicos de pacientes com câncer que sofrem infecção osteorradionecrose por Actinomyces $s p$, para descrever as abordagens e discutir as opções terapêuticas à luz da literatura atual.

PALAVRAS - CHAVE: Actinomicose. Osteorradionecrose. Infecções orais.

\section{REFERENCES}

ABIR, B.; MOUMINE, M.; ABOUCHADI, A.; NASSIH, M.; RZIN, A. L'actinomycose mandibulaire. Rev Stomatol Chir Maxillofac Chir Orale, France, v. 114, n. 6, p. 387-390, 2013.

http://dx.doi.org/10.1016/j.revsto.2013.07.005

ANDREWS, N.; GRIFFITHS, C. Dental complications of head and neck radiotherapy: Part 1. Aust Dent J, Australian, v. 46, n. 2, p. 88-94, 2001.

CHRCANOVIC, B. R.; REHER, P.; SOUSA A. A.; HARRIS M. Osteoradionecrosis of the jaws-a current overview--part 1: Physiopathology and risk and predisposing factors. Oral Maxillofac Surg, Philadelphia, v. 14, n. 1, p. 3-16, 2010. http://dx.doi.org/10.1007/s10006-009-0198-9

CROSSMAN, T.; HAROLD, J. Actinomycosis of the maxilla - a case report of a rare oral infection presenting in general practice. Br Dent J, London, v. 206, n. 4, p. 201-2, 2009.

CURI, M. M.; DIB, L. L.; KOWALSKI, L.P.; LANDMAN, G.; MANGINI C. Opportunistic actinomycosis in osteoradionecrosis of the jaws in patients affected by head and neck cancer: incidence and clinical significance. Oral Oncol, Philadelphia, v. 36, n. 3, p. 294-9, 2000. http://dx.doi.org/10.1016/S1368-8375(99)00080-9

FINLEY, A. M.; BEESON, M. S. Actinomycosis osteomylelitis of the mandible. Am J Emerg Med, Philadelphia, v. 28, n. 1, p. 118.e1-4, 2010.

GOLDBERG, M. H. Diagnosis and treatment of cervicofacial actinomycosis. Oral Maxillofac Surg Clin North Am, Philadelphia, v. 15, n. 1, p. 51-58, 2003. http://dx.doi.org/10.1016/S1042-3699(02)00074-2 
HALL, V. Actinomyces-Gathering evidence of human colonization and infection. Anaerobe, Philadelphia, v. 14, n. 1, p. 1-7, 2008. http://dx.doi.org/10.1016/j.anaerobe.2007.12.001

HANSEN, R.; KUNKEL, M.; KIRKPATRICK, D. J.; WEBER, A. Actinomyces in infected osteoradionecrosis - underestimated? Hum Pathol, Philadelphia, v. 37, n. 1, p. 61-67, 2006. http://dx.doi.org/10.1016/j.humpath.2005.09.018

HANSEN, T.; WAGNER, W.; KIRKPATRICK, C. J.; KUNKEL, M. Infected osteoradionecrosis of the mandible: follow-up study suggests deterioration in outcome for patients with Actinomyces-positive bone biopsies. Int J Oral Maxillofac Surg, Philadelphia, v. 35, n. 11, p. 1001-1004, 2006.

http://dx.doi.org/10.1016/j.ijom.2006.08.006

HANSEN, T.; KUNKEL, M.; SPRINGER, E.; WALTER, C.; WEBER, A.; SIEGEL, E.; KIRKPATRICK, C. Actinomycosis of the jaws - histopathological study of 45 patients shows significant involvement in bisphosphonate-associated osteonecrosis and infected osteoradionecrosis. Virchows Arch, New York, v. 451, n. 6, p. 1009-1017, 2007. http://dx.doi.org/10.1007/s00428-007-0516-2

HAPPONEN, R. P.; VIANDER, M.; PELLINIEMI, L.; AITASALO, K. Actinomyces israelii in osteoradionecrosis of the jaws. Histopatologic and immunocytochemical study of five cases. Oral Surg Oral Med Oral Pathol, St. Louis, v. 55, n. 6, p. 580-588, 1983.

KAPLAN, I.; ANAVI, K.; ANAVI, Y.; CALDERON, S.; SCHWARTZ-ARAD, D.; TEICHER, S.; HIRSHBERG, A. The clinical spectrum of Actinomyces-associated lesions of the oral mucosa and jawbones: correlations with histomorphometric analysis. Oral Surg Oral Med Oral Pathol Oral Radiol Endod, St. Loius, v. 108, n. 5, p. 738-746, 2009.

KHOJASTEPOUR, L.; BRONOOSH, P.; ZEINALZADE, M. Mandibular bone changes induced by head and neck radiotherapy. Indian J Dent Res, Ahmedabad, v. 23, n. 6, p. 774-777, 2012.

http://dx.doi.org/10.4103/0970-9290.111258

LIU, C. J.; CHANG, K. M.; OU, C. T. Actinomycosis in a Patient Treated for Maxillary Osteoradionecrosis. J Oral Maxillofac Surg, Philadelphia, v. 56, n. 2, p. 251-253, 1998. http://dx.doi.org/10.1016/S02782391(98)90880-1

MARX, R. E. Osteoradionecrosis: a new concept of its pathophysiology. J Oral Maxillofac Surg, Philadelphia, v. 41, n. 5, p. 283-288, 1983. http://dx.doi.org/10.1016/0278-2391(83)90294-X

NEVILLE, B. W.; DAMM, D. D.; ALLEN, C. M.; BOUQUOT, J. E. Odontogenic cysts and tumors. In: Neville BW, Damm DD, Allen CM, Bouquot JE, editors. Oral \& Maxillofacial Pathology. 2nd ed. Philadelphia: W B Saunders, 2002. p. 126-8, 180-2, 574-87.

PULVERER, G.; SCHUTT-GEROWITT, H.; SCHAAL, K. P. Human cervicofacial actinomycoses: microbiological data for 1997 cases. Clin Infect Dis, Oxford, v. 37, n. 4, p. 490-497, 2003. http://dx.doi.org/10.1086/376621

SILVESTRE-RANGIL, J.; SILVESTRE, F. J. Clinico-therapeutic management of osteoradionecrosis: a literature review and update. Med Oral Patol Oral Cir Bucal, Valência, v. 16, n. 7, p. e900-4, 2011. http://dx.doi.org/10.4317/medoral.17257

SMITH, M. H.; HARMS, P. W.; NEWTON, D. W.; LEBAR, B.; EDWARDS, S. P.; ARONOFF, D. M. Mandibular Actinomyces osteomyelitis complicating florid cemento-osseous dysplasia: case report. . BMC Oral Health, London, v. 11, p. 21, 2011. http://dx.doi.org/10.1186/1472-6831-11-21 
STORE, G.; ERIBE, E. R.; OLSEN, I. DNA-DNA hybridization demonstrates multiple bacteria in osteoradionecrosis. Int J Oral Maxillofac Surg, Philadelphia, v. 34, n. 2, p. 193-196, 2005.

http://dx.doi.org/10.1016/j.ijom.2004.06.010

TA, R. Agents of actinomycosis. In: MANDELL, G.L.; BENNETT, J. E.; DOLIN R. (Ed.). Mandell, Douglass, and Bennett's Principles and Practice of Infectious Diseases. Philadelphia: Churchill Livingstone Elsevier, v. 2, 2010. p. 3209-3219.

TURNER, L.; MUPPARAPU, M.; AKINTOYE, S. O. Review of the Complications Associated with Treatment of Oropharyngeal Cancer: A guide to the dental practitioner . Quintessence Int, Berlin, v. 44, n. 3, p. 267-279, 2013.

TURNER, L.; MUPPARAPU, M.; AKINTOYE, S. O. Review of the Complications Associated with Treatment of Oropharyngeal Cancer: A Guide to the Dental Practitioner . Quintessence Int, Berlin, v. 44, n. 3, p. 267279, 2013. 